\title{
Development of a Drilling Tool for Making non- Circular Cross-sections of Blastholes at Open-cast Operations
}

\author{
Gennady Buyalich \\ T.F. Gorbachev Kuzbass \\ State Technical University \\ Kemerovo, Russia \\ gdb@kuzstu.ru
}

\author{
Viktor Tatsienko \\ T.F. Gorbachev Kuzbass \\ State Technical University \\ Kemerovo, Russia \\ v.tatsienko@gmail.com
}

\author{
Mikhail Khusnutdinov \\ T.F. Gorbachev Kuzbass \\ State Technical University \\ Kemerovo, Russia \\ hmk.gmk@kuzstu.ru
}

\author{
Polina Podkur \\ T.F. Gorbachev Kuzbass \\ State Technical University \\ Kemerovo, Russia \\ podkurpn@kuzstu.ru
}

\begin{abstract}
In mining minerals by open-cast method, the environment is exposed to a powerful man-made impact, a significant part of which is associated with mass explosions during rock crushing. In preparation of rocks for excavation by blasting, a significant amount of dust and gases is emitted into the atmosphere; therefore, a decrease in the use of explosives is an urgent task both in terms of reducing the cost of blasting operations and from the ecological point of view. This task can be solved by increasing the effectiveness of the explosion. The results of studies of the process of blasting boreholes with a non-circular cross-section confirm the practical need in developing this drilling tool. In using the kinematic method applied in engineering for assigning complex surfaces, the conditions under which it is possible to produce boreholes with a non-circular cross-section are considered. The designs of the drilling tool with variable and fixed linear dimensions are selected which allow formation of a noncircular cross-section of the borehole, their shortcomings have been analyzed. The roller-cutter method for forming a noncircular cross section is substantiated, at which a smaller number of kinematic links of the drilling tool is achieved and a greater number of ways to impact the rock is ensured.
\end{abstract}

Keywords—rock drilling, kinematic analysis of drilling tools, non-circular shape of a borehole, design of the drilling tool, drilling tool roller

\section{INTRODUCTION}

In preparation of rocks for excavation by blasting, a significant amount of explosives is used, as a result a great amount of dust and gases [1] is emitted into the atmosphere. Therefore, a decrease in the use of explosives is an urgent task both in terms of reducing the cost of blasting operations and from the ecological point of view. This task can be solved by increasing the effectiveness of the explosion. Known are the studies of increasing the effective action of an explosion by changing the shape of the cross-section of an elongated charge [2-11]. Charges with a non-circular crosssection can be formed by placing the explosive in blastholes with an appropriate cross-section. On an industrial scale, drilling is the process of obtaining a cavity in rock mainly by rotating the drilling tool and forming a circular cross-section. The known design of the drilling tool for boreholes with noncircular cross section [12], on the basis of their analysis can evaluate the possibility of further improving such a tool.

\section{RESEARCH THEORY}

When drilling a borehole with a non-circular crosssection, it is necessary not only to separate and transport the rock mass in order to form a cavity in the rock, but also to obtain a surface with a more complex shape different from the surface of rotation. Therefore, it is advisable to present drilling as a process of forming a shape - emerging of a surface in time. Theoretical study of the process of shape forming is most thoroughly considered in the metalworking industry, according to which a kinematic method of specifying a surface is used, based on the motion of the line, which represents the geometric locus of the various positions of the generating line. The law of spatial motion of a generatrix is assigned by fixed curves, which are called the guiding lines of a kinematically ruled surface. Thus, any kinematic surface can be obtained with the help of guiding $(L)$ and generatrix $\left(L_{1}\right)$ lines, as shown in Figure 1.

The motions of the shape forming (rock-destroying) elements can be carried out by changing the linear dimensions of the device, as well as by spatial rotational and translational motions. In this case, the cross-sectional dimensions of the resulting borehole are one of the main parameters determining the direction of the drilling tool simulation. Especially it relates to small sizes of a crosssection of the borehole at which it is practical to use the devices, which are not changing the linear sizes in the course of drilling.

On the basis of the functional model of the drilling tool, as shown in Figure 2, the ways of forming a cavity in rock are analyzed, as shown in table 1.

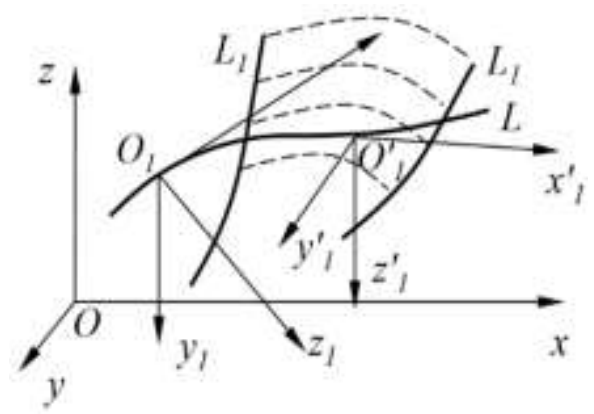

Fig. 1. Scheme of surface formation. 


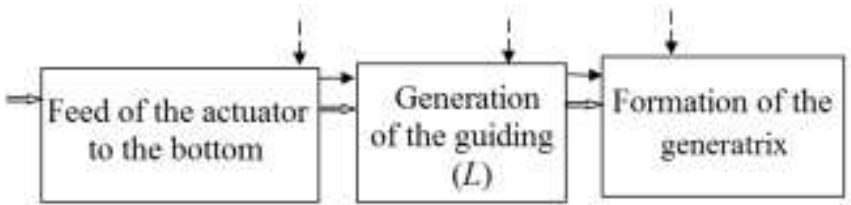

$\longrightarrow$ Pneumatic, hydraulic, electric power

$\longrightarrow$ Mechanical power $\quad \longrightarrow$ Rock response

Fig. 2. Scheme of surface formation.

TABLE I. METHODS OF CAVITY FORMATION IN ROCK WHEN DRILLING BOREHOLES

\begin{tabular}{|c|c|c|c|c|}
\hline \multirow{2}{*}{$\begin{array}{c}\text { Method of } \\
\text { cavity } \\
\text { formation }\end{array}$} & \multicolumn{2}{|c|}{ Method of generating } & \multirow{2}{*}{$\begin{array}{c}\text { Number } \\
\text { of } \\
\text { kinematic } \\
\text { branches }\end{array}$} & \multirow{2}{*}{$\begin{array}{c}\text { Number } \\
\text { of ways } \\
\text { to } \\
\text { impact } \\
\text { rock }\end{array}$} \\
\hline & $\begin{array}{c}\text { Guiding } \\
\text { line }\end{array}$ & Generatrix & & \\
\hline $\begin{array}{l}\text { Rotary } \\
\text { drilling } \\
\text { with } \\
\text { cutting bits }\end{array}$ & \multirow{3}{*}{$\begin{array}{l}\text { Continu } \\
\text { ous } \\
\text { rotation }\end{array}$} & $\begin{array}{l}\text { Continuous } \\
\text { rotation }\end{array}$ & 1 & 1 \\
\hline $\begin{array}{l}\text { Rotary } \\
\text { drilling } \\
\text { with roller } \\
\text { cutters }\end{array}$ & & $\begin{array}{l}\text { Continuous } \\
\text { rotation } \\
\text { (by rolling over) }\end{array}$ & 2 & 3 \\
\hline $\begin{array}{l}\text { Percussion } \\
\text { drilling } \\
\text { with } \\
\text { continuous } \\
\text { rotation }\end{array}$ & & $\begin{array}{l}\text { Continuous } \\
\text { rotation and } \\
\text { intermittent } \\
\text { translational }\end{array}$ & 2 & 2 \\
\hline $\begin{array}{l}\text { Percussion } \\
\text { drilling } \\
\text { with } \\
\text { intermitten } \\
\text { t rotation }\end{array}$ & $\begin{array}{l}\text { Intermit } \\
\text { tent } \\
\text { rotation }\end{array}$ & $\begin{array}{l}\text { Intermittent } \\
\text { translational }\end{array}$ & 2 & 1 \\
\hline $\begin{array}{l}\text { Percussion } \\
\text { non-rotary } \\
\text { drilling }\end{array}$ & $\begin{array}{l}\text { One- } \\
\text { time } \\
\text { activity }\end{array}$ & $\begin{array}{l}\text { Intermittent } \\
\text { translational }\end{array}$ & 1 & 1 \\
\hline
\end{tabular}

With respect to the drilling tool, the number of movements of the system's elements is limited by the bottom of the borehole, which in this case performs the function of the workpiece and is stationary in the general $x y z$ coordinate system, as shown in Figure 1.

Translational motion of the actuator to the bottom of the borehole (feed) is necessary for the operation of any drilling tool. In the simplest designs of the drilling tool, the generation of the guiding and the generating lines occurs either by means of rotation only or only by feeding. This is due to the fact that for the implementation of each type of motion along the generatrix and the guiding line, the actuator has a separate kinematic branch.

\section{RESULTS AND DISCUSSIONS}

With mechanical drilling methods, the tool rotation is used to generate the guiding line $(L)$ and, along with the feed, it is an additional way of transferring energy to the rockbreaking elements. In addition, the rotation of the tool facilitates the movement of the fracture zone over the surface of the borehole bottom, freeing up space for effective removal of drilling fines from the borehole bottom zone. With industrial drilling tools that do not change their linear dimensions during operation, the rotation results in the formation of a cylindrical cavity.
For drilling tools without changing linear dimensions, the formation of a non-circular borehole profile [12] requires the absence of rotation (designs 1 and 2 in Figure 3), as well as the creation of parallel-conjugated cavities (design 5, Figure 3).

For a drilling tool with varying linear dimensions, the formation of a non-circular cross-section of the borehole requires the presence of an additional kinematic link, for example, designs 3, 4, and 7 in Figure 3. An exception is the roller cutter drilling tool (design 8 , Figure 3), in which the "roller cutter-rock" pair is the kinematics link that allows changing of the linear dimensions [13].

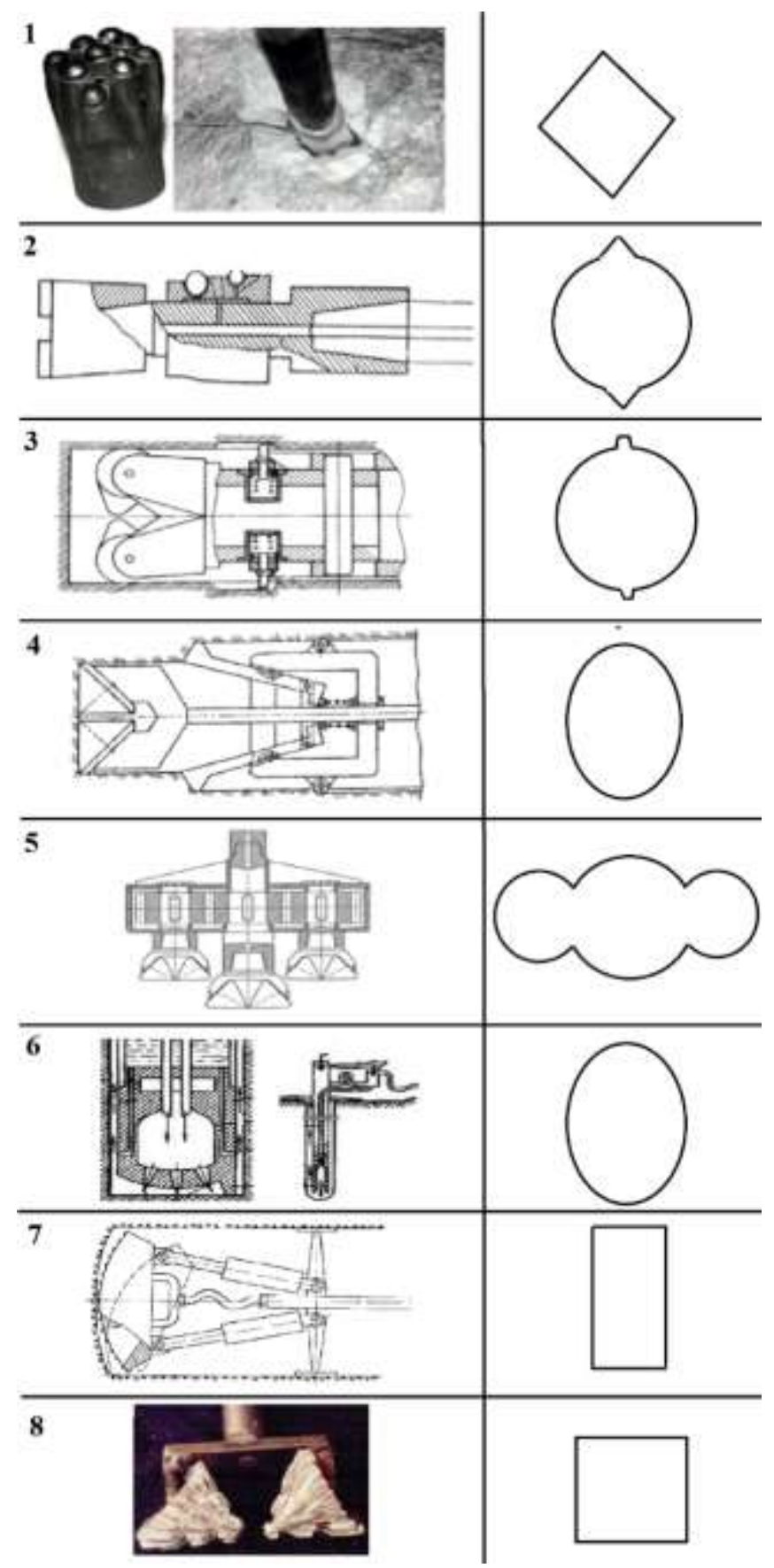

Fig. 3. Designs of a drilling tool and the resulting shapes of the crosssection.

The "rolling body-rock" pair in the design of the toothed disk cutting bit has been used to alternately bring in contact 
with the rock material of the cutting elements without changing the linear dimensions of the tool when drilling boreholes with a circular cross-section. In design 8 , as shown in Figure 3, the change in the linear dimensions and the radius of the fractured cross-section of the borehole when the tool rotates occurs by alternately bringing into contact with the rock a variable length of the lines forming the cone of cutters when they roll along the borehole bottom around the well axis.

Based on the analysis of the drawbacks of the drilling tools considered, as shown in table 2 , it can be concluded that for drilling of boreholes with a non-circular crosssection in open pit mining, the most rational is the use of a rotary drilling tool, which effectively cleans the bottomhole zone from drill cuttings, a small number of kinematic branches of the structure and a greater number of ways of destroying impact on rock.

Single-cone roller cutters can form a cross-section in the form of regular flat figures, as shown in Figure 4. In terms of the effectiveness of the explosion, cross-sectional shapes with a smaller number of angles and a concave wall shape are preferable [14].

TABLE II. DESIGN FEATURES OF DRILLING TOOLS (FIG.3) PRODUCING A NON-CIRCULAR CROSS-SECTION OF A BOREHOLE

\begin{tabular}{|c|c|c|c|}
\hline $\begin{array}{l}\text { Variant } \\
\text { of } \\
\text { drilling } \\
\text { tool } \\
\text { design } \\
\text { (Fig. 3) }\end{array}$ & $\begin{array}{l}\text { Number } \\
\text { of } \\
\text { kinematic } \\
\text { branches }\end{array}$ & $\begin{array}{l}\text { Method of } \\
\text { impact on } \\
\quad \text { rock }\end{array}$ & Shortcomings \\
\hline 1 & 1 & $\begin{array}{l}\text { Percussive } \\
\text { translational }\end{array}$ & \multirow{3}{*}{$\begin{array}{l}\text { The size of the breaking zone } \\
\text { is limited due to its inefficient } \\
\text { cleaning from drilling fines }\end{array}$} \\
\hline 2 & 2 & $\begin{array}{l}\text { Percussive } \\
\text { translational }\end{array}$ & \\
\hline 3 & 1 & $\begin{array}{l}\text { Cutting } \\
\text { translational }\end{array}$ & \\
\hline 4 & 2 & $\begin{array}{l}\text { Cutting } \\
\text { translational } \\
\text { rotary }\end{array}$ & $\begin{array}{l}\text { The presence of an additional } \\
\text { pair of friction poorly } \\
\text { protected from the } \\
\text { environment. Change in the } \\
\text { load on the drilling tool, } \\
\text { depending on the angle of its } \\
\text { rotation in the borehole. }\end{array}$ \\
\hline 5 & 3 & $\begin{array}{l}\text { Cutting } \\
\text { percussive } \\
\text { crushing } \\
\text { rotary }\end{array}$ & $\begin{array}{l}\text { Complex structure due to the } \\
\text { presence of bottom hole } \\
\text { gearbox }\end{array}$ \\
\hline 6 & - & $\begin{array}{l}\text { Thermal } \\
\text { rotary }\end{array}$ & $\begin{array}{l}\text { High energy consumption of } \\
\text { the thermal method of rock } \\
\text { breaking }\end{array}$ \\
\hline 7 & 3 & $\begin{array}{l}\text { Crushing } \\
\text { translational } \\
\text { rotary }\end{array}$ & $\begin{array}{l}\text { Complex structure due to the } \\
\text { use of bottom hole hydraulic } \\
\text { motors }\end{array}$ \\
\hline 8 & 2 & $\begin{array}{l}\text { Percussive } \\
\text { and } \\
\text { crushing, } \\
\text { rotary }\end{array}$ & $\begin{array}{l}\text { Change in the load on the } \\
\text { drilling tool, depending on the } \\
\text { angle of its rotation in the } \\
\text { borehole. }\end{array}$ \\
\hline
\end{tabular}

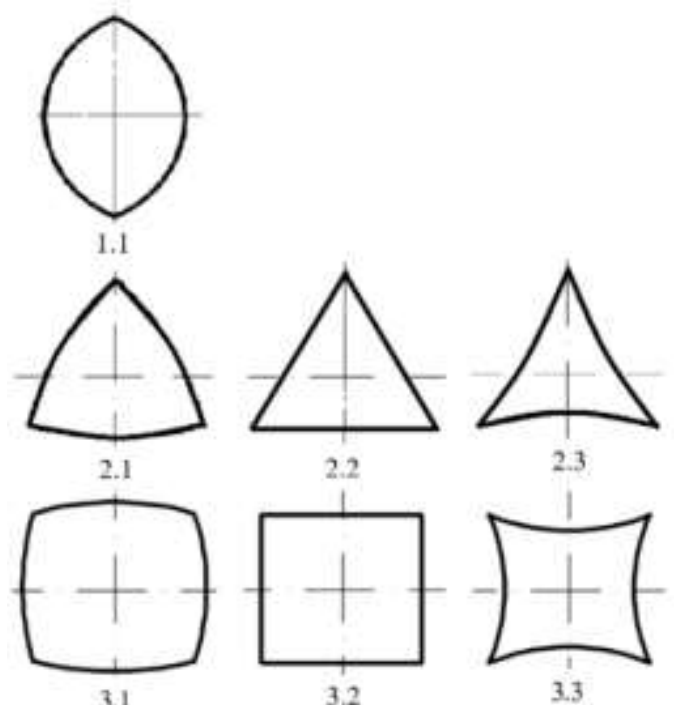

Fig. 4. Variants of shapes of borehole cross-section.

The number of angles is determined by the ratio of the roller bit and the shape of the cutters. It has been found out that with the help of bits having one, two, three cutters, it is possible to produce boreholes with a concave shape of their bottom and a regular cross-sectional shape having rectilinear, convex and concave parts of the sides except for the shape in the form of a regular triangle that can be obtained only by one roller cutter, as shown in table 3.

The cutters can be used in a combined drilling tool, where they are given the role of forming a non-circular cross-section of the borehole. In this case, in order to simplify the design, the generation of the generatrix must take place also by a continuous rotational motion, as, for example, in the design of a cutting-type roller bit (Figure 5).

\section{CONCLUSIONS}

The use of the kinematic method for specifying the surface with respect to the process of drilling boreholes with a non-circular cross-section makes it possible to draw the conclusion that in the design of a drilling tool it is preferable to create the generatrix and the guide using one and the same method. In this case, the design of the drilling tool is simplified due to the reduction of the number of kinematic links. In the variants of the drilling tool, where the guide is generated by the rotational motion, the cleaning of the borehole bottom zone from the drill fines is improved. The roller cutter drilling tool which is most prevalent in open-cast mining has the features mentioned above. The use of rolling cutters to form boreholes with a non-circular cross-section allows implementation of the rock destruction without increasing the number of kinematic branches of the drilling tool design using the rotational motion of the tool necessary to effectively clean the borehole bottom zone from the drilling fines. By varying the cone angles of the cutters, it is possible to obtain the correct cross-sectional shapes of a borehole with a convex, rectilinear or concave wall with a drilling tool containing one, two or three cutters. Further studies should be aimed at studying the oscillating processes during drilling [15] caused by non-circular shape of the cross-section, as these processes affect the strength of the drilling tool design [16]. 
TABLE III. DESIGN PARAMETERS OF THE DRILLING TOOL FOR OBTAINING A NON-CIRCULAR SHAPE OF THE CROSS-SECTION

\begin{tabular}{|c|c|c|c|c|c|c|c|c|c|c|c|c|c|c|c|c|}
\hline \multirow[b]{2}{*}{$\begin{array}{l}\text { Para- } \\
\text { meter }\end{array}$} & \multicolumn{16}{|c|}{ Shape variant (Fig. 4) } \\
\hline & \multicolumn{3}{|c|}{1.1} & \multicolumn{3}{|c|}{$\begin{array}{l}2.1 \\
2.3\end{array}$} & \multicolumn{3}{|c|}{2.2} & \multicolumn{3}{|c|}{$\begin{array}{l}3.1 \\
3.3 \\
\end{array}$} & \multicolumn{3}{|c|}{3.2} & $\begin{array}{l}3.1 \\
3.2 \\
3.3\end{array}$ \\
\hline $\begin{array}{l}\text { Number } \\
\text { of } \\
\text { angles }\end{array}$ & \multicolumn{3}{|l|}{2} & \multicolumn{6}{|l|}{3} & \multicolumn{7}{|c|}{4} \\
\hline $\begin{array}{l}\text { Gear } \\
\text { ratio }\end{array}$ & \multicolumn{3}{|l|}{2} & \multicolumn{6}{|c|}{1,5} & \multicolumn{6}{|c|}{2} & $4 / 3$ \\
\hline $\begin{array}{l}\text { Max. } \\
\text { tapering } \\
\text { angle of } \\
\text { cutter }\end{array}$ & - & - & - & - & & & \multicolumn{3}{|c|}{82.2} & - & & & \multicolumn{3}{|c|}{54.65} & - \\
\hline $\begin{array}{l}\text { Min. } \\
\text { tapering } \\
\text { angle of } \\
\text { cutter }\end{array}$ & & $\begin{array}{l}- \\
-\end{array}$ & ? & & $\begin{array}{l}\infty \\
\text { ¿ } \\
\infty\end{array}$ & $\underset{\infty}{0}$ & & & ल. & & - & : & - & & ?ֶ? & - \\
\hline $\begin{array}{l}\text { Possible } \\
\text { number } \\
\text { of } \\
\text { cutters }\end{array}$ & 1 & 2 & 3 & 1 & 2 & 3 & 1 & - & - & 1 & 2 & 3 & 1 & 2 & 3 & 1 \\
\hline
\end{tabular}

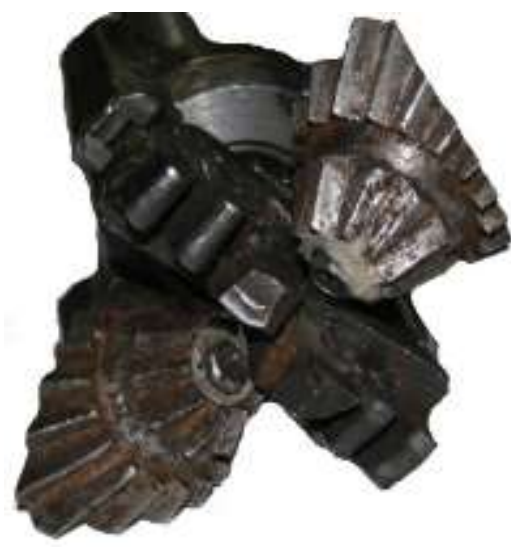

Fig. 5. Combined cutting-type roller cutter drilling tool for generation of a square cross-section of a borehole.

\section{REFERENCES}

[1] A. Abdollahisharif, E. Bakhtavar, and H. Nourizadeh, "Green biocompatible approach to reduce the toxic gases and dust caused by the blasting in surface mining," Environmental Earth Sciences, vol. 75(3), p. 191, 2016.

[2] José A. Sanchidrián, P. García-Bermudez, and Carlos L. Jimeno, "Optimization of granite splitting by blasting using notched holes,"
International Journal for Blasting and Fragmentation, vol. 4, pp. 1-11, 2000.

[3] S.H. Cho, Y. Nakamura, B. Mohanty, H.S. Yang, and K. Kaneko, "Numerical study of fracture plane control in laboratory-scale blasting," Engineering Fracture Mechanics, vol 75, pp. 3966-3984, 2008.

[4] F. Ouchterlony, M. Olsson, and S. O. Båvik, "Perimeter blasting in granite with holes with axial notches and radial bottom slot" International Journal for Blasting and Fragmentation, vol 4, pp. 55-82, 2000.

[5] Z.-X. Zhang, "Chapter 10 - Single-Hole Blasting," Rock Fracture and Blasting, pp. 217-236, 2016.

[6] W. Yan-mei, and Li Cheng-fang, "Blasting compare analysis on spiral notching and circle borehole," Chongqing architecture, vol 11, pp. 51$53,2005$.

[7] D. Dexing, and Zhv. Chenghang, Theoretical and experimental studies an fracture plane control blast with notched boreholes," Trans Nonferrous Metals Soc China, vol 1, pp. 188-191, 1999.

[8] S. S. Rathore, and S. Bhandari, "Controlling measures of damages due to various blasting techniques in splittable sandstone quarry during extracting," J InstnEngrs-Pt MN, vol. 88, pp. 33-39, February 2008.

[9] C. E. Tsoutrelis, N. Gikas, P. Nomikos, and G. Exadaktylos, "Use of notched boreholes for fracture controlled blasting in the ornamental stone quarries," International Journal for Blasting and Fragmentation, vol. 1, pp. 445-463, 1997.

[10] Y. Zhongwen, G. Yang, and W. Xu, "Experimental study of crack propagation under blasting load in notched boreholes," Chinese Journal of Rock Mechanics and Engineering, vol. 34(10), pp. 20182026, 2015.

[11] Y. Musong, Y. Yongqi, Y. Renshu, Z. Qi, and J. Qiankun, "Model experimental study on mechanism of borehole directed fracture blasting," Explosion and shock waves, vol. 17(2), pp. 159-165, 1997.

[12] I. A. Zhukov, L. T. Dvornikov, and S. M. Nikitenko, "About creation of machines for rock destruction with formation of apertures of various cross-sections," IOP Conference Series: Materials Science and Engineering, vol. 124, p. 012171, 2016.

[13] G. Buyalich, and M Khusnutdinov, "Justification of the shape of a non-circular cross-section for drilling with a roller cutter," E3S Web of Conferences. - EDP Sciences, vol. 21, p. 6, 2017.

[14] G. Buyalich, and M Khusnutdinov, "Analysis of cross-sectional shapes of borehole," IOP Conf. Series: Earth and Environmental Science. - IOP Publishing, vol. 87, p. 5, 2017.

[15] E.N. Pashkov, G.R. Zijakaev, and M.V. Tsigankova, "Differential equations of processes for the hydropuls power mechanism of drill machines," Applied Mechanics and Materials, vol. 379, pp. 91-94, 2013

[16] G. D. Buyalich, A. V. Anuchin, and K. P. Serikov, "Influence of the Geometry of Beveled Edges on the Stress-Strain State of Hydraulic Cylinders," IOP Conf. Series: Materials Science and Engineering, 2016, 127: 012012 